\section{Different ways with glasnost}

\section{London}

MR Mikhail Gorbachev, the Soviet president and Party general-secretary successfully tied up London traffic for two days last week, made a speech at the Guildhall, had lunch with the British Queen, who accepted his invitation to visit the Soviet Union at a "convenient" time.

The official visit to London followed one to Cuba, both of which had been postponed in December on account of the Armenian earthquake. But the changed itinerary allowed Gorbachev to meet the Prime Minister of the Irish Republic during a stopover on the outward journey.

The three visits showed some interesting contrasts in the exercise of glasnost. In Ireland, Gorbachev stressed his concept of a "common European home" in language apparently innocent of Ireland's jealously guarded neutrality, but agreed with Mr Charles Haughey on further economic collaboration in fishing, shipbuilding and barter in food products.

Gorbachev promised to raise in London two human-rights issues arising from the continuing conflict in Ulster (Northern Ire land), but declined to suggest a political solution for the conflict.

In Cuba, where President Fidel Castro has so far proved remarkably resistant to perestroika, the emphasis was on continuing friendship. The two leaders signed a new treaty of cooperation in science and NEWS IN BRIEF

\section{New radiotelescope}

\section{Bangalore}

Under a new agreement, India and the Soviet Union will jointly fabricate and install a radiotelescope in South India. The telescope will form part of an eastern hemisphere very-long-baseline interferometer. It will be linked to the baseline connecting similar radiotelescopes at Ussurisk and Ephpatoria in the Soviet Union.

R. R.

\section{Prisoners freed}

\section{Washington}

Twelve Somali scientists, engineers and medical doctors were freed from prison earlier this month, according to two committees of the US National Academy of Sciences and the Institute of Medicine which had taken up their cause. A report published by the two committees last year accused the Somali government of torturing prisoners and of detaining them for years without formal charges (see Nature 331, 196; 1988). Somali Prime Minister Lt General Mohamed Ali Samantar promised in a speech in Washington last month that his government would release the prisoners. technology, and promised improved contacts in "science, culture, education, health-care, the press, radio, television, cinema, tourism and sport".

But Gorbachev gave a clear warning against the "export of revolution" from Cuba to Latin America and visited a science exhibition showing a new highpowered sugar-cane harvester, a microanalysis system for blood testing and a model of the Juragua nuclear power station being built with Soviet assistance.

In Britain, Gorbachev used his Guildhall speech to announce that the Soviet Union has ceased the production of weapons-grade plutonium, and that it is about to do the same for weapons-grade uranium. This was described by the US State Department as an "empty gesture" on the grounds that the recycling of existing stocks of fissile material should suffice for many years to come. Mrs Thatcher, the British Prime Minister, rather emphasized her view that nuclear weapons provide a stronger peace-keeping deterrent than conventional forces.

On the human rights front, the Gorbachev visit was marked by the arrival in London of mathematician Georgii Samoilovich, long denied an exit visa on the grounds of his access to classified information 17 years ago. He is to undergo urgent treatment for a leukaemic condition.

Although the Soviet and British governments agreed during the visit on further cooperation in the arts and trade, little was said at the formal level about science and technology. The Soviet offer to find a place on a future space mission for a British astronaut, now made unconditionally, seems to have run into British unwillingness to meet the costs entailed.

Professor Vitalli Goldanskii, director of the Institute of General Physics in Moscow, well-known in Britain as the chairman of the Soviet Pugwash committee, was prominent among $\mathrm{Mr}$ Gorbachev's advisers during the whole week. As one of the first to recognize that some radioactive nuclei may emit particles heavier than $\alpha$-particles, he was one of those who visited the Atomic Energy Research Establishment to inspect the still-negative attempts to replicate electrolytic fusion. He was also eager to explain to all enquirers how he proposes, as part of perestroika, to split his Moscow institute into several autonomous units, each with a separate director.

Gorbachev himself visited a British factory manufacturing communications equipment supplied to the Soviet Union and Izvestia took the occasion to lecture the West on the iniquities of the Cocom ban on the export of sensitive technology to the Socialist bloc.

Vera Rich

\section{Remote-sensing satellite for Iraq}

\section{São Paulo}

Brazil's Institute of Space Research (INPE) is considering a proposal to build a remotesensing satellite with military potential for Iraq. Brazil was an important supplier of arms to Iraq during the Iran - Iraq war.

INPE, together with Brazil's aircraft manufacturer, Embraer, and private companies would build the body of the satellite using technology INPE has acquired for its own programme to construct four satellites. Brazil will have its first satellite ready by the end of the year, although it may have to wait until 1992 for an indigenous launch. The development of the Satellite Launch Vehicle by the Air Force is behind schedule.

The first two Brazilian satellites will be small (115 kg) test capsules. Remote-sensing satellites of similar size will then be launched. INPE also has an agreement with China to design a bigger remotesensing device.

Iraq is thought to be interested in help in establishing a satellite-building and testing facility. The sophisticated camera required for military sensing would come from a French company. But the deal appeaars to be encountering opposition inside Brazil's Foreign Ministry. INPE's director-general, Marcio Nogueira Barbosa, said he would prefer to pass INPE's satellite-construction technology to private companies.

Ricardo Bonalume Neto

\section{AUSTRALIA}

\section{Study planned of greenhouse effect}

\section{Sydney}

A YEAR after rejecting a request for $A \$ 1$ million to support research into the greenhouse effect, the Australian government has changed its mind and agreed to spend A $\$ 7.8$ million on the same topic over the next 15 months.

The Prime Minister, Bob Hawke, explained the turn-around by stressing the "dramatic explosion of awareness" of the greenhouse effect over the last year.

Part of the A\$7.8 million will be used to set up a National Greenhouse Advisory Committee of six experts to help the government to set research priorities. A\$5.54 million will go to the Commonwealth Scientific and Industrial Research Organization (CSIRO) and the Bureau of Meteorology to continue research into predictive modelling. The remainder will support Australian participation in international research programmes.

The government has also promised to help countries in the Pacific region that will be affected by changes in sea level.

Tania Ewing 